\title{
Chinese pond mussel Sinanodonta woodiana (Lea, 1834) (Bivalvia): origin of the Polish population and GenBank data
}

\author{
Marianna SOROKA, ${ }^{1}$ Maria URBAŃSKA, ${ }^{2 *}$ Wojciech ANDRZEJEWSKI ${ }^{3}$ \\ ${ }^{1}$ Department of Genetics, University of Szczecin, Felczaka 3c, 71-412 Szczecin; ${ }^{2}$ Department of Zoology, Institute of Zoology, Poznań \\ University of Life Sciences, Wojska Polskiego 71C, 60-625 Poznań; ${ }^{3}$ Department of Division of Inland Fisheries and Aquaculture, \\ Institute of Zoology, Poznań University of Life Sciences, Wojska Polskiego 71C, 60-625 Poznań, Poland \\ *Corresponding author: urbanska@up.poznan.pl
}

\begin{abstract}
DNA sequences of the mitochondrial cox1 gene were analysed in 4 new local populations of Sinanodonta woodiana (Bivalvia) in Poland, in the first reported Polish population, and in a population from Hungary. The gene sequences of Polish specimens were identical to those of specimens from Hungary, Italy and Ukraine, but different from those of Romanian specimens (data from GenBank). According to fish farm documentation, S. woodiana had spread in Poland by 2 routes: i) direct import of fish infected by glochidia of S. woodiana from Hungary; and ii) indirectly, by the major distributor of thermophilous fish in Poland, Gostawice Fish Farm, which started to import Hungarian fish in the 1960s. The genetic analysis and available documentation unambiguously confirm that Polish populations of S. woodiana derive from a source population in Hungary. In addition, we noticed doubtful identification of this species in GenBank data and further research is needed to resolve this problem.
\end{abstract}

Key words: Bivalves, freshwater mussels, invasive species, Chinese pond mussel, mitochondrial DNA, cox1.

Received: February 2014. Accepted: April 2014.

\section{INTRODUCTION}

Knowledge of the origin of the Chinese pond mussel Sinanodonta woodiana, recorded in Poland since the 1990s, is based on import data about exotic fish, which most probably carried its glochidia and in this way introduced this bivalve species to Polish waters, giving rise to numerous local populations (Protasov et al., 1993; Kraszewski and Zdanowski, 2001). This has led to the hypothesis that populations of $S$. woodiana appeared in Polish waters as a result of fish import from Hungary, mostly cyprinid fish species, such as bighead carp (Aristichthys nobilis, Richardson, 1845) and silver carp (Hypophthalmichthys molitrix, Valenciennes, 1844). However, there was no available published research to confirm this hypothesis.

The first genetic studies of $S$. woodiana, from warm water bodies, show a low genetic variation between specimens of the first Polish population (Soroka and Zdanowski, 2001; Soroka, 2005). In case of some water bodies with natural water temperature, which are used as fish ponds, documentation shows that the imported fry originated from Gosławice Fish Farm, belonging to the Konin heated lakes system. Gosławice Fish Farm bought earlier the fish in Hungary. In other places where the mussel $S$. woodiana is found, populations may be of different origin, as this species could have invaded Poland by many routes.

The aim of this study was to determine if the individ- uals of $S$. woodiana found in various localities in Poland were derived from a single source population in Hungary, which would be consistent with documentation of fish import to Poland, or there exist some different, unknown and undocumented sources of introduction of this bivalve species to Poland. The genetic analysis of several Polish and Hungarian specimens allowed also an assessment of the mode and routes of its invasion into Poland. Additionally, the obtained mitochondrial DNA sequences were compared with available GenBank data for this species. Moreover, we examined the documentation of fry origin in the fish farms where material for genetic research was collected.

\section{METHODS}

Detailed characteristics of the Polish localities, i.e. ponds Urocze, Wojnowice, Polna Rzeka, and Oko, as well as Gosławice Fish Farm, were presented in earlier works (Soroka and Zdanowski, 2001; Urbańska et al., 2012; Andrzejewski et al., 2013). For this study, specimens of $S$. woodiana were collected from 4 new localities (fish ponds in various parts of Poland), and compared with specimens from Gosławice Fish Farm (near Konin, Poland) and from the River Danube (south of Budapest, Hungary) (Fig. 1).

Genetic analyses were performed for the 5 Polish populations, each represented by 3 randomly selected individuals, and for 5 individuals from Hungary. Total DNA 
was isolated from gills of 20 specimens. The standard phenol/chloroform extraction and ethanol precipitation were used (Skibinski et al., 1994). The PCR reaction was performed with primers LCO1490 and HCO2198 (Folmer et al., 1994) for the mitochondrial cytochrome $c$ oxidase subunit I (coxl) gene. The PCR conditions were as follows: initial denaturation for $2 \mathrm{~min}$ at $96^{\circ} \mathrm{C}$, followed by 5 cycles of $30 \mathrm{~s}$ at $95^{\circ} \mathrm{C}, 1 \mathrm{~min}$ at $45^{\circ} \mathrm{C}, 1.5 \mathrm{~min}$ at $72^{\circ} \mathrm{C}$, followed by 28 cycles of $30 \mathrm{~s}$ at $95^{\circ} \mathrm{C}, 45 \mathrm{~s}$ at $55^{\circ} \mathrm{C}, 1 \mathrm{~min}$ at $72^{\circ} \mathrm{C}$, and a final extension for $7 \mathrm{~min}$ at $72^{\circ} \mathrm{C}$. The total volume of each PCR reaction mixture was $20 \mu \mathrm{L}$. After $1 \%$ agarose gel electrophoresis, the amplification products were viewed under UV light. The results were saved and the size of the PCR products was analysed with Vision Works ${ }^{\mathbb{R}}$ LS Analysis Software (UVP, Cambridge, UK). PCR products were purified using Clean-up columns (A\&A Biotechnology, Gdynia, Poland) and cycle-sequenced in both directions (by Macrogen, Seoul, South Korea, http://dna.macrogen.com/eng/). Both DNA strands were assembled into consensus using DNAMAN 5.2.9 software (Lynnon, Quebec, Canada). The haplotypes for the coxl gene of the specimens were submitted to GenBank and their accession numbers are: KJ125078 and KJ125079 for Polish and Hungarian speciments, respectively. The $\operatorname{cox} 1$ sequences were aligned using ClustalW program, being a part of MEGA4 software (Tamura et al., 2007). This program was also used to calculate sequence divergence (Kimura 2-parameter, K2P, and Maximum Composite Likelihood, MCL, distances). MEGA4 was applied to phylogeny reconstruction with minimum evolution approach (Swofford et al., 1996, Nei and Kumar 2000) with K2P and MCL distances.

We also analysed the documentation of the fish farms from which the material for analyses was collected, to identify the sources of introduced fish fry and of the parasitic glochidia of $S$. woodiana encysted on the fry, which gave rise to populations of this accidentally introduced bivalve species.

\section{RESULTS}

For 15 individuals of $S$. woodiana from 5 Polish populations, identical haplotypes were obtained for the mitochondrial coxl gene fragment, with a mean length of 661 bp. For 5 individuals of this species from the Danube in Hungary, also identical haplotypes were obtained for the analysed coxl fragment, with a mean length of $662 \mathrm{bp}$. Haplotypes from Poland and Hungary showed 100\% similarity to sequences of $S$. woodiana from Italy and Ukraine, whereas significant differences were observed (about 6\%) in comparison with individuals from Romania (Tab. 1). Blast analyses in GenBank confirmed our observations and showed that the obtained sequences have only $95 \%$ sequence identity with $S$. woodiana from Romania and $100 \%$ with specimens from Italy and Ukraine.
Fish farm documentation indicates that $S$. woodiana had spread in Poland by 2 routes. In ponds Urocze and Wojnowice, the mussels arrived with fish directly from Hungary. By contrast, in ponds Polna Rzeka and Oko, the mussels arrived with fish indirectly, from Gosławice Fish Farm, which in the 1960s introduced large amounts of thermophilous fish from Hungary (Fig. 1).

\section{DISCUSSION}

The Chinese pond mussel, distributed also in Europe, was initially named Anodonta woodiana (Petró, 1984; Kiss and Pekli, 1988; Nagel et al., 1996; Piechocki and

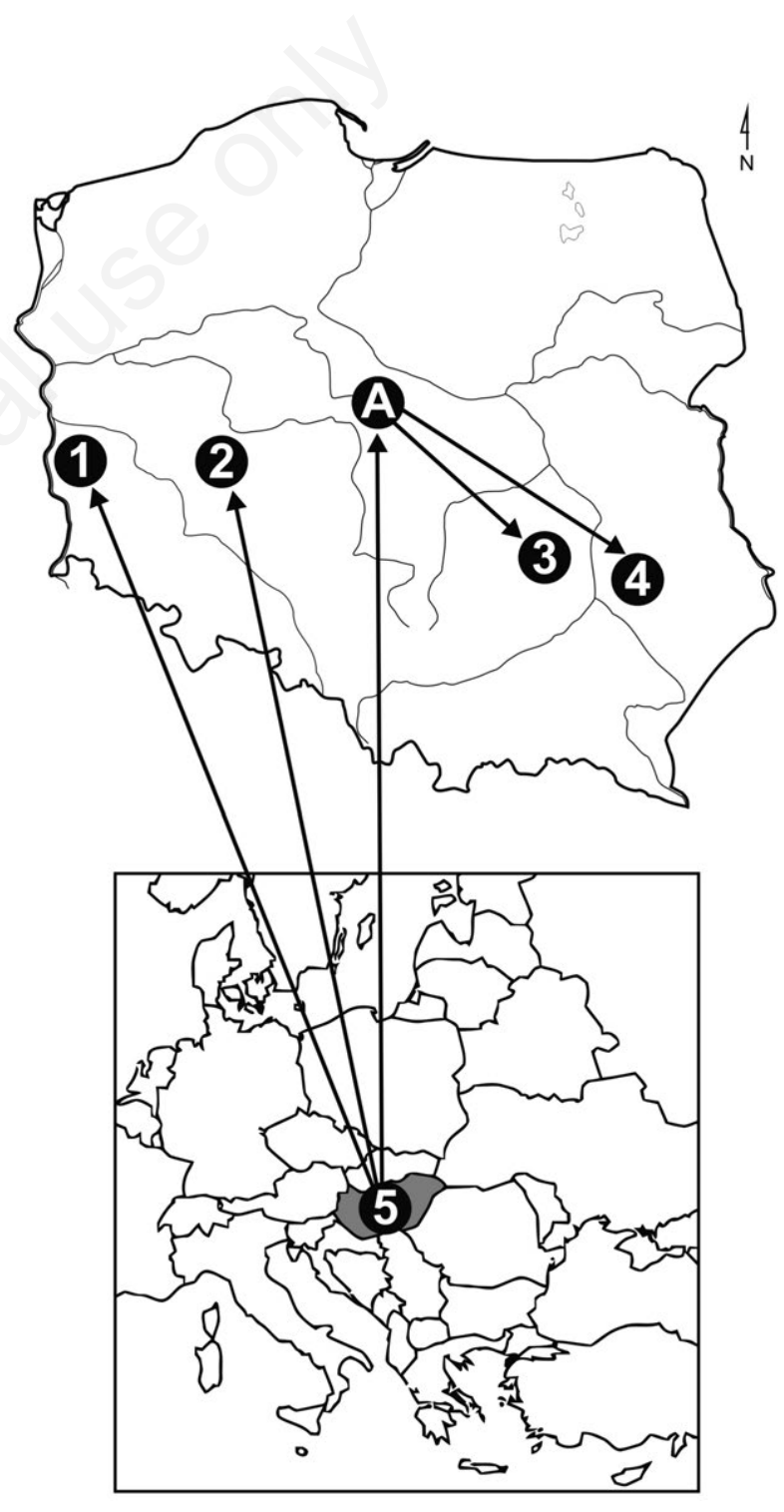

Fig. 1. Directions of spread of Sinanodonta woodiana in Poland. Sampling sites in ponds Urocze (1), Wojnowice (2), Polna Rzeka (3), Oko (4), and in the River Danube (5). Gosławice Fish Farm is marked with A. 
Riedel, 1997; Watters, 1997; Kraszewski and Zdanowski, 2001; Soroka, 2005, 2008a). Currently it is assigned to the genus Sinanodonta Modell, 1945 (Beran, 1997, 2008; Bohme, 1998; Falkner et al., 2001; Yurishinets and Korniushin, 2001; Domagała et al., 2007; Gąbka et al., 2007; Popa et al., 2007; Munjiu and Shubernetski, 2008; Cappelletti et al., 2009; Soroka, 2010; Popa et al., 2011). Mitochondrial cytochrome $c$ oxidase subunit I gene cox I is used most often for species identification and phylogenetic analyses. In over $95 \%$ of animal species, characteristic sequences are found within this gene, and its 5'-region, $648 \mathrm{bp}$ long, is used to create the huge Barcode of Life Database (Hebert et al., 2003a, 2003b; Ratnasingham and Hebert, 2007). The international GenBank database includes sequences for the $\operatorname{cox} 1$ gene fragment of mussels identified as A. woodiana or S. woodiana, showing similarity of $100 \%$ to $95 \%$, or even only $91 \%$ (using Basic Local Alignment Search Tool, BLAST). Here we use the name $S$. woodiana, and sequences of $A$. woodiana from GenBank should not be treated as a separate species.

So far, studies of European species of Unionidae have revealed a low variation within the coxl gene (less than $1 \%$ ) in Unio gibbus, U. pictorum and U. tumidus, as well as Anodonta anatina (Källeresjö et al., 2005, Araujo et al. 2009 , Soroka 2008b, 2010). A higher intraspecific variation of the coxl gene was reported for the gastropod Sadleriana fluminensis (3\%) (Szarowska and Falniowski, 2013) and Potamilus species (2.6\%) (Roe and Lydeard, 1998). The highest differences (about 7\%) were found be-

Tab. 1. Genetic distances computed with K2P (below diagonal) and MCL (above diagonal) between the studied specimens of $S$. woodiana and sequences from GenBank.

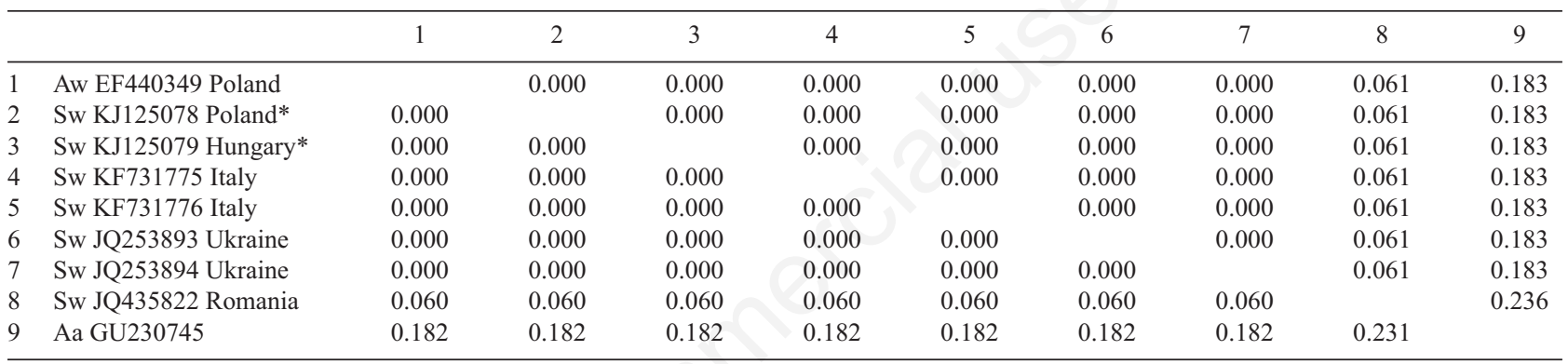

Sw, Sinanodonta woodiana; Aw, Anodonta woodiana; Aa, Anodonta anatine; ${ }^{*}$ novel sequences.

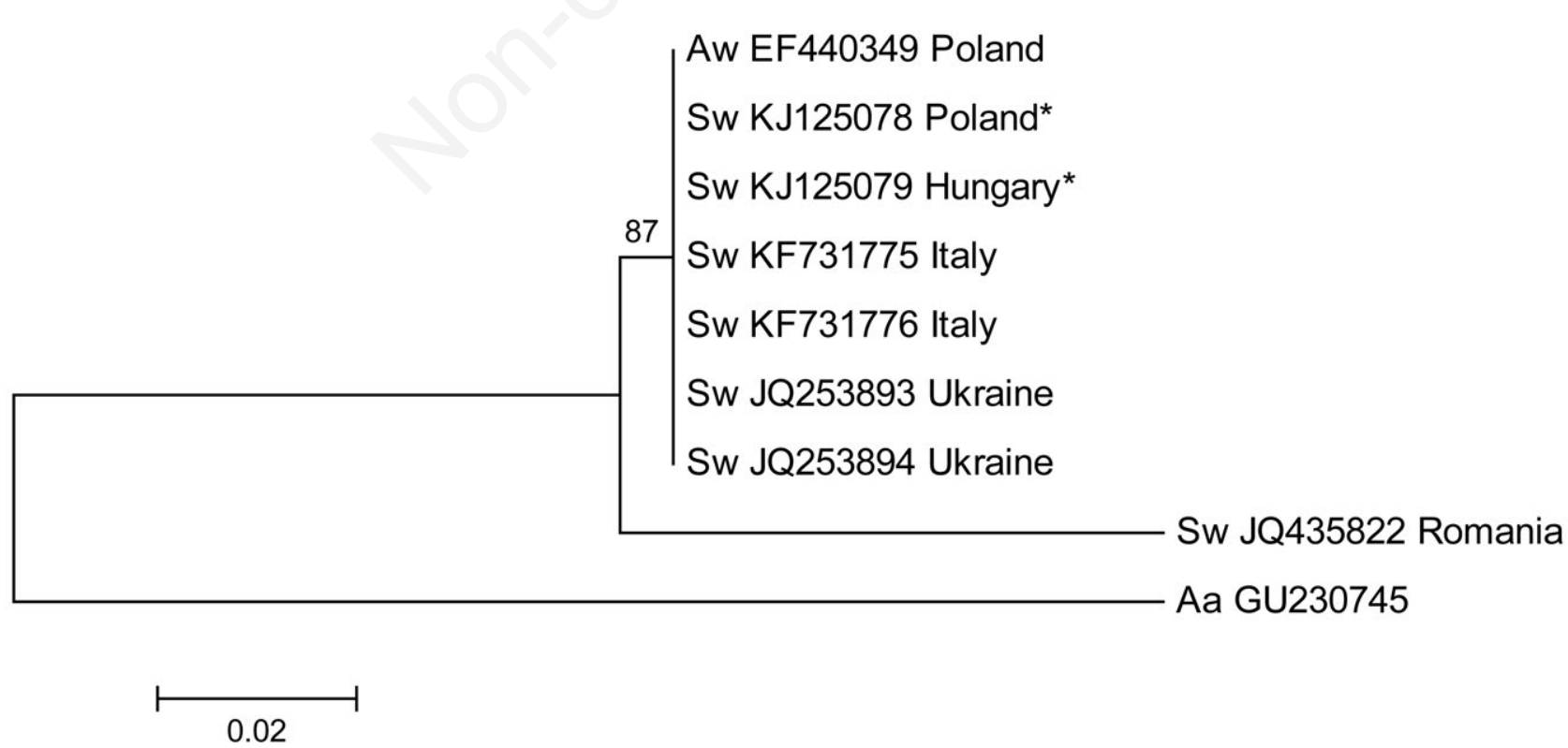

Fig. 2. Minimum-evolution tree computed with Kimura 2-parameter distances. Values above branches represent bootstrap support (2000 replicates). Sw, Sinanodonta woodiana; Aw, Anodonta woodiana; Aa, Anodonta anatine; "novel sequences. 
tween syntopic S. fluminensis and S. robici specimens, which confirms species distinctness of these 2 lineages (Szarowska and Falniowski, 2013). Specimens of $S$. woodiana from 5 analysed Polish populations had identical sequences of the mitochondrial coxl gene fragment. They did not differ from those of individuals from other populations in Poland (Soroka, 2010), Hungary, Italy, and Ukraine (Tab. 1, Fig. 2). All the dendrograms showed the same topology of the analysed sequences, so only one of them with higher bootstrap values is presented in Fig. 2 . This provides strong evidence that these European local populations may derive from one source population and for specimens in Poland it was Hungarian population, as indicated by both fish farming records and molecular data. By contrast, specimens of $S$. woodiana from Romania show a higher genetic variation (about 6\%) as compared to other European populations. Such a high variation may attest to 2 distinct routes of migration of founder individuals of these European populations, and show a high intraspecific variation of this species.

\section{CONCLUSIONS}

Earlier research on Polish populations of $S$. woodiana shows significant differences in biometric parameters of individuals from various locations (Soroka and Zdanowski, 2001; Urbańska et al., 2012; Andrzejewski et al., 2013). The observed phenotypic variation of individuals of $S$. woodiana coming from different Polish ponds seemed to indicate varied provenance of these mussel populations, but molecular data do not confirm that assumption. Their coxl gene sequences suggest that all the analyzed Polish specimens derive from Hungarian specimens. The phenotypic variation is probably linked with environmental factors, while the lack of genetic variation of the coxl gene sequence between the Hungarian and Polish individuals of $S$. woodiana seems to be a result of the founder effect.

\section{ACKNOWLEDGMENTS}

We thank Dr Viktoria Takacs for help in collection of individuals of $S$. woodiana from Hungary.

\section{REFERENCES}

Andrzejewski W, Urbańska M, Mazurkiewicz J, Gierszal H, Golski J, 2013. The current invasion status of Anodonta woodiana (Lea, 1934) in Poland - study of habitat parameters. Oceanol. Hydrobiol. St. 42:173-180.

Araujo R, Toledo C, Machordom A, 2009. Redescription of Unio gibbus Spengler, 1793, a west Palaearctic freshwater mussel with hookless glochidia. Malacologia 51:131-141.

Beran L, 1997. First record of Sinanodonta woodiana (Mollusca: Bivalvia) in the Czech Republic. Acta Societatis Zoologicae Bohemicae 61:1-2.

Beran L, 2008. Expansion of Sinanodonta woodiana (Lea, 1834)
(Bivalvia: Unionidae) in the Czech Republic. Aquatic Invasions 3:91-94.

Bohme M, 1998. [Ein neuer Fundort der Chinesischen Teichmuschel (Sinanodonta woodiana) in Mitteleuropa].[Article in German]. Heldia 2:166.

Cappelletti C, Cianfanelli S, Beltrami ME, Ciutti F, 2009. Sinanodonta woodiana (Lea, 1834) (Bivalvia: Unionidae): a new non-indigenous species in Lake Garda (Italy). Aquatic Invasions 4:685-688.

Domagała J, Łabęcka AM, Migdalska B, Pilecka-Rapacz M, 2007. Colonisation of the channels of Międzyodrze (NorthWestern Poland) by Sinanodonta woodiana (Lea, 1834) (Bivalvia: Unionidae). Pol. J. Nat. Sci. 22:679-690.

Falkner G, Bank RA, Proschwitz TV, 2001. Check-list of the non-marine Molluscan species-group taxa of the States of Northern, Atlantic and Central Europe (CELECOM I). Heldia 4:1-76.

Folmer O, Black M, Hoeh W, Lutz R, Vrijenhoek R, 1994. DNA primers for amplification of mitochondrial cytochrome $c$ oxidase subunit I from diverse metazoan invertebrates. Mol. Mar. Biol. Biotech. 3:294-299.

Gąbka M, Dolata PT, Antonowicz R, 2007. New localities of the Chinese clam Sinanodonta woodiana (Lea, 1834) (Bivalvia, Unionidae) in the Barycz River Valley (Wielkopolska Region). Folia Malacologica 15:71-74.

Hebert PDN, Cywinska A, Ball SL, Dewaard JR, 2003a. Biological identifications through DNA barcodes. P. Roy. Soc. Lond. B Bio 270:313-321.

Hebert PDN, Ratnasingham S, Dewaard JR, 2003b. Barcoding animal life: cytochrome $c$ oxidase subunit 1 divergences among closely related species. P. Roy. Soc. Lond. B Bio 270:96-99.

Källersjö M, Von Proschwitz T, Lundberg S, Eldenäs P, Erséus C, 2005. Evaluation of ITS rDNA as a complement to mitochondrial gene sequences for phylogenetic studies in freshwater mussels: an example using Unionidae from north-western Europe. Zoologica Scripta 34:415-424.

Kiss Á, Pekli J, 1988. On the growth rate of Anotonta woodiana (Lea 1834) (Bivalvia: Unionacea). Bull. Univ. Agric. Sci. Gödöllö 1:119-124.

Kraszewski A, Zdanowski B, 2001. The distribution and abundance of the Chinese mussel Anodonta woodiana (Lea, 1834) in the heated Konin lakes. Arch. Pol. Fish. 9:253-265.

Munjiu O, Shubernetski I, 2008. First record of Sinanodonta woodiana (Lea, 1834) (Bivalvia: Unionidae) in Moldova. Aquatic Invasions 3:441-442.

Nagel K, Badino G, Alessandria B, 1996. Population genetics of European Anodontinae (Bivalvia: Unionidae). Journal of Mollusca Studies 62:343-357.

Nei M, Kumar S, 2000. Molecular evolution and phylogenetics. Oxford University Press: 333 pp.

Petró E, 1984. The occurrence of Anodonta woodiana woodiana in Hungary. Állattanu Közl. 71:189-191.

Piechocki A, Riedel A, 1997. Mollusca. In: J. Razowski (ed.), Checklist of the animals of Poland. Instytut Systematyki i Ewolucji Zwierząt PAN, Kraków 4:104-121.

Popa OP, Kelemen BS, Murariu D, Popa LO, 2007. New records of Sinanodonta woodiana (Lea, 1834) (Mollusca: Bivalvia: Unionidae) from Eastern Romania. Aquatic Invasions 2:265-267. 
Popa OP, Popa LO, Krapal A-M, Murariu D, Iorgu EI, Costache M, 2011. Sinanodonta woodiana (Mollusca: Bivalvia: Unionidae): isolation and characterization of the first microsatellite Markers. Int. J. Mol. Sci. 12:5255-5260.

Protasov AA, Afanasjev SA, Zdanowski B, 1993. [Natural selfpurification system of the Konin lakes].[Article in Polish]. Komun. Ryb. 6:6-9.

Ratnasingham S, Hebert PDN, 2007. bold: The barcode of Life Data System (http://www.barcodinglife.org). Mol. Ecol. Notes 7:355-364.

Roe KJ, Lydeard C, 1998. Molecular systematics of the freshwater mussel genus Potamilus (Bivalvia: Unionidae). Malacologia 39:195-205.

Skibinski DOF, Gallagher C, Beynon CM, 1994. Sex-limited mitochondrial DNA transmission in the marine mussel Mytilus edulis. Genetics 138:801-809.

Soroka M, 2005. Genetic variability among freshwater mussel Anodonta woodiana (Lea, 1834) (Bivalvia: Unionidae) populations recently introduced in Poland. Zool. Sci. 22:11371144.

Soroka M, 2008a. Doubly uniparental inheritance of mitochondrial DNA in the freshwater bivalve Anodonta woodiana (Bivalvia: Unionidae). Folia Biologica (Krakow) 56:91-95.

Soroka M, 2008b. Identification of gender-associated mitochondrial haplotypes in Anodonta anatina (Bivalvia: Unionidae). Folia Malacologica 16:21-26.

Soroka M, 2010. Characteristics of mitochondrial DNA of unionid bivalves (Mollusca: Bivalvia: Unionidae). I. Detection and characteristic of double uniparental inheritance (DUI) of unionid mitochondrial DNA. Folia Malacologica 18:147188.

Soroka M, Zdanowski B, 2001. Morphological and genetic variability of the population of the population of Anodonta woodiana (Lea, 1834) occurring in the heated Konin lakes system. Arch. Pol. Fish. 9:239-252.

Swofford DL, Olsen GJ, Waddell PJ, Hillis DM, 1996. Phylogenetic inference, p. 407-514. In: D.M. Hillis, C. Moritz and B.K. Mable (eds.), Molecular systematics. Sinauer Ass., Inc.

Szarowska M, Falniowski A, 2013. Species distinctness of $\mathrm{Sa}$ dleriana robici (Clessin, 1890) (Gastropoda: Rissooidea). Folia Malacologica 21:127-133.

Tamura K, Dudley J, Nei, M, Kumar S, 2007. MEGA4: Molecular Evolutionary Genetics Analysis (MEGA) Software Version 4.0. Mol. Biol. Evol. 24:1596-1599.

Urbańska M, Łakomy A, Andrzejewski W, Mazurkiewicz J, 2012. The story of one clam. Probably the oldest location of the Chinese pond mussel Sinanodonta woodiana (Lea, 1834) (Bivalvia, Unionidae) in Poland. Int. J. Oceanogr. Hydrobiol. 41:41-45.

Yurishinets VI, Korniushin, AV, 2001. The new species in the fauna of Ukraine Sinanodonta woodiana (Bivalvia: Unionidae), its diagnostics and possible ways of introduction. Vestnik Zoologii 35:79-84.

Watters GT, 1997. A synthesis and review of the expanding range of the Asian freshwater mussel Anodonta woodiana (Bivalvia: Unionidae). Veliger 40:152-156. 